\title{
É prajá!
}

\section{Mauro Pergaminik Meiches}

ma reflexão, uma obra de arte, um gesto a respeito do fim, implica necessariamente a volta a algum começo. Nada disso é estranho ao Teatro da Vertigem. Para encenar o atual (em muitos sentidos) Apocalipse 1,11, o grupo, mais uma vez, parece ter exigido de seus componentes o confronto com uma condição que, desde sempre, deu início àquilo que podemos nomear de estético. Neste teatro, o ator deve passar a habitar aquela fina faixa da existência onde o mítico que nos assola e sua metabolização por meio de qualquer representação se encontram. Espaço exíguo, onde a transformação da matéria bruta está sempre ameaçada de fracasso.

$\mathrm{O}$ risco parece fazer parte de um ideal programático. Ao escolher como esteio de trabalho o livro bíblico do Apocalipse, de saída, já está dada uma aposta de alta monta. E a tradução que nos é oferecida por Fernando Bonassi, com dramaturgismo de Luciene Guedes e direção de Antonio Araújo, executa deslocamentos poderosos neste texto que promete, para alguns apenas, a redenção. $\mathrm{O}$ "1,11" do título já faz menção aos excluídos de um momento histórico que efetivamente não se rege pelo tempo mítico da Bíblia ou de qualquer outra mitolo- gia. E o espetáculo (que palavra indevida!) coloca em contato, naquilo que é possível, o seu público com este outro a quem o título faz referência.

É difícil usar as categorias conceituais a que estamos acostumados. Ambientado em um reformatório, nome tergiverso de penitenciária, mal cabe pensar o espaço do espetáculo como cenografia. Parece insuficiente. Da mesma maneira que em o Livro de Jó, outra incursão bíblica do grupo, a ambientação do espetáculo envolve o espectador chamando-o para uma descida aos infernos, num movimento que, parodiando o nome do grupo, é vertiginoso. Como para todos, afinal, não há perdão para esta alma que se propôs acompanhar não de todo desinteressadamente esta peripécia. Digo isto porque quem procura a grande metáfora que a arte tem a função de tecer para a sociedade que a abriga, está tentando desobrigar-se de alguma coisa. Ao contrário do que suspeitamos, quando nos enchemos de boas intenções para apreciar qualquer manifestação deste campo, para depois da experiência também nos regozijarmos de um certo cabedal que acaba de ser incorporado (e domesticado, diga-se de passagem), procuramos os objetos de arte na esperança de que eles, ou

Mauro Pergaminik Meiches é psicanalista, autor de Uma pulsão espetacular (São Paulo, Escuta/FAPESP, 1997) e A travessia do trágico em análise (São Paulo, Casa do Psicólogo/FAPESP, 2000). 
quem deles se ocupou para sua construção, nos aliviem de um contato que, a princípio, parece insuportável, com a assim chamada matéria bruta da existência.

No Teatro da Vertigem, seus componentes realizam a experiência desta dificuldade, sem que o resultado teatral perca a vibração da intensidade de um tal contato. O risco em que é colocado, até certo ponto, o espectador, foi vivido e será revivido a cada dia pelo ator. A cada dia é muito tempo! Corresponde à reposição do bruto e do trágico da vida que nos assola ininterruptamente. Curiosa reedição da tranche de vie naturalista!

Estrebuchando em uma passarela estreita, transando em cena, urinando e sendo urinado, subindo em uma precária escada em cuja base se ateia fogo, recebendo ovos crus arremessados de uma certa distância, dependurando-se para encenar um enforcamento a uma altura bastante razoável, além de suportar um dos textos mais cruéis já escritos, que reverbera quase todas as vociferações do preconceito - talvez o pior enfrentamento para o ator -, este risco filtra, para quem assiste, a intensidade da experiência, sem contudo atenuá-la em demasia. Isto seria uma degradação.

O risco físico - houve de fato atores que se feriram - quer fazer encarnar a experiência. Ele faz uma espécie de âncora para a metáfora libertária do espetáculo: é preciso, para haver libertação, experimentar a violência e a opressão fisicamente impostas. Se estamos situados no terreno onde o mítico pode encontrar alguma forma de metáfora que o traduza, não podemos navegar estas águas sem levar em conta, inapelavelmente, a crueldade, já dizia Artaud.

Não só o texto realiza o papel de toda metáfora que é o de transportar algo de um lugar para outro. $\mathrm{O}$ ambiente do presídio já nos desloca por si só, assim que passamos o primeiro portão. Quem pôde projetar/construir um lugar como esse, que leva o nome irônico de reformatório? Quem consegue se reformar ali? Aliás, o que é a reforma de alguém? Apocalipse 1,11 não deixa estas perguntas ecoarem no vazio. Porém, a saída para isso virá na forma de um pedido, não de uma resposta assertiva.

O livro do Apocalipse é narrado por João, apóstolo de Cristo. João, em Apocalipse 1,11 , um retirante desvalido, assiste calado ao desenrolar dos acontecimentos que culminam no julgamento dos homens por esta instância que marca na carne, há milênios, nossa subjetivação. É notável a serenidade da personagem de João. Suas cenas contrastam com a estridência geral do espetáculo, exceção feita ao seu primeiro encontro com os anjos rebeldes e poderosos. Este João, marcado por uma interiorização que será o eixo de seu questionamento do divino, ou do poder (!), literalmente agarra o $\mathrm{Se}$ nhor Morto e confessa seu medo de que "tudo isso só esteja acontecendo aqui, dentro da minha cabeça”. Começa aí uma verdadeira saraivada de perguntas que o espetáculo formula: estarei testemunhando ou alucinando uma situação? Quem, em sã consciência, pode responder a isso com certeza? Será possível (será o Benedito?) que alguém tenha sido reformado aqui?

$\mathrm{Na}$ versão do Teatro da Vertigem, João não apenas narrará o que testemunhou. Esta fímbria de densidade subjetiva - estamos afinal no fim do século XX, marcado em demasia por uma noção de sujeito portador de interioridade, sem falar do limiar de um novo milênio -, ganhará corpo no final para completar a tradução do Apocalipse. Nesta versão, o fim não será para instaurar o reino de Deus, mas para pensar um reino sem Ele.

Acompanhemos outros deslocamentos não menos pungentes que o espetáculo realiza. Muito diferente dos "reis da Terra" que na Bíblia habitam Babilônia, aqui, Babilônia, a grande prostituta, é acompanhada por uma apoteose de excluídos. A Boite Nova Jerusalém, irônica versão da Jerusalém celeste, abriga emblematicamente o negro, o índio, o animalzinho, a deficiente, a bicha e a puta. $\mathrm{O}$ ar é quase irrespirável, tal como o ar de um presídio. Estes, tal como os reis do Testamento, serão punidos. Mais uma vez. E mais outra, se for preciso... 
Apocalipse 1,11 afronta seu espectador. As cenas são perturbadoras, agressivas, não acreditamos no que estamos ouvindo. O texto faz emergir, sem meias palavras, tudo o que a hipocrisia reprimiu. Assim, é possível pensar numa desestabilização da função mediadora da palavra, não por um trabalho formal no plano do significante, mas pelo próprio retorno do recalcado, com sua avassaladora aparição na superfície da vida de vigília. E isso tem um efeito devastador na audiência.

Desta Jerusalém podre, corrupta e insuportável, somos deslocados (nós também) para o corredor polonês da morte, que, aí sim, encena diretamente o massacre do Carandiru, quando morreram, oficialmente, 111 presos. Foram mais, muitos mais, e o igualmente perturbador livro de Dráuzio Varella, Estação Carandiru, narra este massacre e a vida na cadeia. Este corredor se abre para algumas celas mal iluminadas: nelas se pode experimentar a sensação de estar enterrado vivo. De fato, a palavra cenografia soa insuficiente. Ela poderia construir um espaço que fosse "tal como qualquer coisa", mas não a coisa em si, pouquíssimo mediada por qualquer linguagem. É apenas a clausura e sua experiência asfixiante que se abre para o espectador. De certa maneira, ele também deixou de sê-lo para padecer, quase miticamente, a brutalidade do acontecimento. Assim, este teatro aproxima de maneira pungente atores e público. Estamos no mesmo barco...

O espetáculo não faz concessões nisto que reverbera uma denúncia. E ele as enfrenta à maneira como Lesky classifica Antígona: um conflito cerradamente trágico. Ao olharmos o que acontece com esta galeria de excluídos, damo-nos perfeitamente conta de uma situação sem solução. Não há montante de solidariedade e justiça que possa com tudo isto que a cena escancara sem meias palavras. A saída tem que ser proposta de maneira mais contundente.

Por uma escada difícil, mas nem de longe tão frágil como aquela que os atores usarão na terceira parte do espetáculo, o público desce para o pátio onde se dará o julgamento. É um pátio de dois andares, cercado de celas, um cenário foucaultiano que abole qualquer privacidade. Ali, não há para onde olhar; o olhar não pode se perder. Muito próprio para a encenação do Juízo Final. Os mesmos excluídos são submetidos a julgamento e punidos de maneira hedionda em cena aberta. Exatamente como na vida cotidiana fazemos com as palavras para segregar aqueles que são os diferentes. Falta perguntar: diferente de quem? Quem é igual?

Não sobrará ninguém, nem o Juiz. Num enforcamento terrível de assistir, ele põe fim à sua função e à cena. Sua última fala é: "quem vai me salvar de mim? Quem é que vai me salvar de mim?"

É a vez de João agora dialogar com o Senhor. E pedir a Ele para deixá-lo só, para que possa tentar de um outro jeito, começar de novo. Bela maneira de se referir a um fim. E este pedido nada suplicante tem foco. Diz João: "Eu gostaria de respirar, andar, de vez em quando ter a sensação de que eu cheguei em algum lugar... É só isso... Tá muito difícil com você aqui. Eu gosto muito de você, mas... tá muito... tá muito difícil...”

João pede para experimentar a existência sem a interferência desta promessa de infinito. Ele quer chegar em algum lugar, ter um ponto de parada. Na finitude talvez possamos equacionar as exclusões. Se deixarmos de adiar a redenção, o presente poderá se tornar mais solidário e - por que não? - feliz!

Muitas, mas muitas mesmo são as possibilidades interpretativas que esse final abre para o espectador. Antes delas, porém, convém contar um último passo. O Senhor concorda em deixar João seguir seu caminho. Em seguida, este convida o público a acompanhá-lo para fora do ambiente do espetáculo, ou seja, para fora do presídio. Um longo corredor tem de ser percorrido. Mas as lufadas de ar se fazem sentir cada vez mais intensamente, completando uma metáfora que fala de liberdade. Esta é relativa, sabemos, mas aponta para perguntas de alto teor revolucionário. 
Além de uma certa fraternidade evidente, gostaríamos de pensar de outro jeito, com outras categorias, equacionar nossa dimensão temporal de maneira diferenciada. Somos perseguidos por certas questôes, e consumimos boa parte da vida na tentativa de respondê-las. $\mathrm{O}$ começo e o fim, por exemplo. $\mathrm{Ou}$, na sua figuração bíblica, a gênese e o apocalipse. Seria possível escapar do caráter compulsório destas indagações? Quem nos outorga certas categorias pelas quais somos obrigados a pensar? Quem, de novo, nos impinge enigmas aos quais somos obrigados a responder?

Talvez, de maneira um pouco fácil, e covarde, poderíamos dizer que a condição de seres de linguagem nos condena a isto. Certo, é um bom reconhecimento. Melhor é aquele ofertado pelo Teatro da Vertigem: saímos do teatro cheios de perguntas e sem nenhuma resposta. Por ter tocado nossa carne, a indagação pulsa: como viver despido das promessas de eternidade? O que é possível realizar para angariar, agora, mais um tanto de liberdade e justiça? 